\title{
FINANCIAL REPORTING OF COMPREHENSIVE INCOME IN THE FOOD AND BEVERAGE SECTOR IN THE REPUBLIC OF SERBIA
}

\author{
Vladimir Obradovićc ${ }^{1}$, Nemanja Karapavlovic ${ }^{2}$
}

\begin{abstract}
Summary
The paper discusses financial reporting of comprehensive income of companies in the food and beverage sector in the Republic of Serbia. The aim of the research is to examine whether the introduction of the concept of net comprehensive income has brought significant information for users of financial statements. The analysis has been conducted on a sample of 132 companies from the mentioned sector on the basis offinancial statements for 2014. We find that there is very high positive correlation between net income and net comprehensive income; that there is no statistically significant difference between net income and net comprehensive income; that there is no statistically significant difference between the return on equity calculated by using net income and the return on equity calculated by using net comprehensive income; and that net comprehensive income is more volatile in time than net income.
\end{abstract}

Key words: net comprehensive income, net income, net other comprehensive income, food and beverage sector

JEL: M41, Q19

\section{Introduction}

Financial reporting is an externally oriented segment of accounting information system dealing with presentation of financial statements and related information to different users. It arose as a response to information needs of users (Stefanović, 1993) and adapts to continuous changes in those needs. During the 20th century, financial reporting has evolved from a relatively simple practice primarily aimed at small groups of industrialists and financiers to a complex process important for many members of modern industrial society (Baker, Walage, 2000). The adaption of financial reporting to the changes in business environment during

1 Vladimir Obradović Ph.D., Assistant Professor, University of Kragujevac - Faculty of Economics, Đure Pucara Starog Street no. 3, Kragujevac, Serbia, Phone: +381 34303590 , E-mail: vobradovic@kg.ac.rs

2 Nemanja Karapavlović M.Sc., Assistant, University of Kragujevac - Faculty of Economics, Đure Pucara Starog Street no. 3, Kragujevac, Serbia, Phone: +381 34303 528, E-mail: nkarapavlovic@kg.ac.rs

EP 2017 (64) 1 (113-128) 
the last decades has included introduction of new types of financial statements and changes in guidelines (rules, principles) for recognition and measurement of financial statements positions (Škarić-Jovanović, 2016).

One of the major recent changes in financial reporting of many companies in the Republic of Serbia is the imposition of obligation to present the amount and components of net comprehensive income. This obligation is a consequence of changes in International Accounting Standard 1: Presentation of Financial Statements. For the first time, the annual sets of financial statements of many entities (companies) in the Republic of Serbia for 2014 incorporate the Statement of other comprehensive income, beginning with net income, as reported in the Income statement, with addition of components of other comprehensive income in order to compute net comprehensive income. Although net comprehensive income is a relatively new concept, its foundations were set earlier, with the introduction of positions arising from non-owner transactions and events that are directly included in owners' equity but that are not part of net income (Obradović, Karapavlović, 2015). The occurrence of net comprehensive income denoted a departure from traditional approach in determining income based on focusing on revenues and expenses, and a reorientation to the approach based on focusing on assets and liabilities (Wilson, 2007). Net comprehensive income, as a new performance measure, broader than traditional net income, includes all the changes in owners' equity resulting from non-owner transactions and events.

The subject of research in this paper is the practices of financial reporting on net comprehensive income of companies in the food and beverage sector in the Republic of Serbia. The aim of the research is to examine whether, in the case of companies in this sector, changes in the way of presentation of income, in terms of introducing the new concept and components of income, has brought significant information for users of financial statements in comparison to the previously reported information. In order to examine the extent of the abovementioned changes, we analyze the relationship between net income and net comprehensive income with the intention to identify whether they are significantly different or not. In addition, we examine volatility over time of net income and net comprehensive income in order to come to the conclusion which one of them is more volatile, i.e., which one of them is subject to greater fluctuations over time.

With regard to the assumption that net comprehensive income is introduced to be a new performance measure with different informational value than the traditional net income, we formulated the research hypotheses as follows:

$\mathrm{H}_{1}$ : There is no correlation between net income and net comprehensive income.

$\mathrm{H}_{2}$ : There is statistically significant difference between net income and net comprehensive income.

$\mathrm{H}_{3}$ : There is statistically significant difference between the return of equity computed by using net income as numerator and the return on equity computed by using net comprehensive income as numerator.

$\mathrm{H}_{4}$ : Net comprehensive income is more volatile in time than net income. 
The rest of the paper is structured in four sections. In the first section, we explain the research sample and methodology. In the second section, we discuss the origin, foundations and importance of comprehensive income. In addition, we present the results of previous empirical research. In the third section, we present the research results. In the final section, we present our conclusions.

\section{Research sample and methodology}

The research encompasses 132 companies in the Republic of Serbia that belong to the food and beverage sector. The analysis is based on the financial statements for 2014, which are available at the internet site of The Serbian Business Registers Agency (http://www.apr.gov. rs). The collected data is processed by using the IBM SPSS Statistics software package and Microsoft Excel. Financial statements for 2014 are of special importance, because of the fact that those financial statements are the first annual statements in which entities in the Republic of Serbia present the total as well as the components of net comprehensive income. In addition to data for 2014, the analyzed financial statements contain comparative data for the year before (2013), which is in accordance with IFRS. Sample structure is shown in Table 1.

In order to test the research hypotheses, we have used the next statistic techniques: descriptive statistics, dispersion measures and Wilcoxon Signed Ranks as a non-parametric alternative to paired-sample t-test. We have used confidence level $(\alpha)$ of 0.05 and 0.01 to determine statistical significance.

Table 1. Sample structure

\begin{tabular}{|c|c|c|}
\hline & Number & Percentage share \\
\hline Prevailing activity & & \\
\hline Production & 128 & 96.97 \\
\hline Trade & 4 & 3.03 \\
\hline Size & & \\
\hline Micro & 2 & 1.51 \\
\hline Small & 34 & 25.76 \\
\hline medium-sized & 51 & 38.64 \\
\hline Large & 45 & 34.09 \\
\hline Legal form & & 59.09 \\
\hline limited liability company & 78 & 37.12 \\
\hline stock company & 49 & 2.27 \\
\hline Cooperative & 3 & 0.76 \\
\hline Entrepreneur & 1 & 0.76 \\
\hline social enterprise & 1 & \\
\hline${ }^{*}$ Classification is based on the 2013 Accounting Law. & \\
\hline \multicolumn{2}{|l|}{} & \\
\hline \multicolumn{2}{|l|}{} & \\
\hline
\end{tabular}

Source: Authors' calculation 


\section{Literature review}

\section{The origin and theoretical background of comprehensive income}

Comprehensive income is not a new concept (Foster, Hall, 1996; Reither, Smith, 1996; Munter, 1997). According to Foster and Hall (1996), the increasing use and importance of financial instruments and fair value as the basis for their measurement influenced the introduction of comprehensive income. Comprehensive income was formally introduced in accounting literature in 1980, in the Statement of Financial Accounting Concepts (SFAC) No. 3: Elements of Financial Statements of Business Enterprises published by the U.S. Financial Accounting Standards Board (FASB). In the mentioned document (paragraph 56), comprehensive income is defined as "the change in equity (net assets) of a business enterprise during a period resulting from transactions and other events and circumstances from nonowner sources". It was introduced to be a broader measure of performance than net income by including all the changes in owners' equity during a period, except those referring to owners' investments and distribution to owners (Yen, Hirst, Hopkins, 2007). In June 1997, the FASB published the Statement of Financial Accounting Standards (SFAS) No. 130: Reporting Comprehensive Income, which requires reporting of comprehensive income to be a part of regular financial reporting (Brauchle \& Reither, 1997) in the form of a statement on the same level of importance as the other financial statements (Yen, Hirst, Hopkins, 2007). SFAS 130 allowed comprehensive income to be displayed in three ways: (1) as the last item of a single statement of comprehensive income, (2) in a separate financial statement supplementing income statement, or (3) in the statement of changes in owners' equity (Rees, Shane, 2012).

Reporting of comprehensive income, in its current form, was introduced in International Financial Reporting Standards (IFRS) in September 2007, when the revised International Accounting Standard (IAS) 1: Presentation of Financial Statements was issued (Rees, Shane, 2012). IAS 1 defines comprehensive income in the substantially same manner as SFAC 3. According to IAS 1, entities can choose between presenting (a) a single statement of comprehensive income displaying net income (profit or loss) and components of other comprehensive income, or (b) two statements - the statement of net income (profit or loss) and the statement of comprehensive income beginning with net income (profit or loss) and displaying components of other comprehensive income. The version of IAS 1 applicable before the aforementioned changes, like the U.S. SFAS 130, allowed the components of other comprehensive income to be displayed within statement of changes in owners' equity. However, that option was removed in 2007, with a consequence in a clearer separation of owner and non-owner changes in equity (Deloitte Touche Tohmatsu, 2007). The same option was also removed from the U.S. Generally Accepted Accounting Principles (GAAP) (Eaton, Easterday, Rhodes, 2013). The consensus on two identical options for displaying comprehensive income is one of many steps towards the convergence between IFRS and the U.S. GAAP (Henry, 2011).

The specified definition of comprehensive income is based on equity (net assets) as a category of the statement of financial position (balance sheet). This indicates that the statement of financial position takes precedence over the income statement (profit or loss statement), 
which was the primary financial statement in the periods of domination of historical cost accounting. The concept of comprehensive income is based on the premise that recognition and measurement of assets and liabilities are the key financial reporting issues, and that comprehensive income can be understood as a total of realised trade transactions and value changes (Walton, 2011).

Comprehensive income in net amount, i.e, after taxation, is a sum of (1) net income (profit or loss), reflecting the amount after deducting income tax, and (2) net other comprehensive income, i.e., other comprehensive income after tax on other comprehensive income. Net income, in general, is a measure of management efficiency in procurement of inputs, transforming inputs into outputs and selling outputs to consumers. Net income shows "the amount of value added in a business cycle beginning with the procurement of production factors and ending with the sale of products to customers. This value added (income) is the basis for assessing performance of management in the realization of the business plan" (Škarić-Jovanović, 2010, 106). Net income is a sum of operating income, financial income and other income, less income tax. Net income calculated in accordance with current IFRS, as opposed to net income in earlier periods, includes the effects of changes in fair value (gains or losses) of the items of statement of financial position, such as investment property, biological assets, and financial assets and liabilities held for trading (except the changes in fair value of liabilities held for trading resulting from changes in credit risk, which are components of other comprehensive income - Melville, 2011). Regardless of the fact that changes in fair value of those assets and liabilities are not realised in current period, they are expected to be confirmed in the market in the short term. The inclusion of such unrealised items in net income is justified by the fact that ability of managers to make gains on changes in value of certain assets and liabilities could be useful for the assessment of managers' efficiency, in addition to their performance in core activities and performance in goods and services markets. Expected gain from the changes in value of the mentioned items is exactly one of the key reasons for their holding. Some assets (e.g., non-investment property, plant and equipment) are purchased to be used, so changes in their values are of secondary importance for the assessment of managers' efficiency.

Net other comprehensive income reflects the changes in owners' equity during a period arising from non-owner transactions (transactions other than contributions by and distributions to owners) that are directly included in owners' equity and that do not affect net income. It includes changes in the value of assets and liabilities that are not held because of expected value changes. Changes in revaluation surplus related to property, plant, equipment and intangible assets, remeasurements of defined benefit plans, and gains or losses arising from translating financial statements of a foreign operation are some examples of components of other comprehensive income. Components of other comprehensive income can be divided into (a) those that can be subsequently (in future periods) included in net income, and (b) those that cannot be subsequently included in net income. Subsequent inclusion of components of other comprehensive income into net income, frequently referred to as "reclassification" (Needles, Powers, 2013), occurs in a moment of disposition of corresponding assets or settlement or transfer of liabilities, when gains or losses become realised. The reclassification 
is necessary in order to "avoid double counting items in comprehensive income that also appear in net income and that have been included in comprehensive income in a previous period" (Munter, 1997).

Net comprehensive income is more complete performance measure than net income, because it better reflects economic events during an accounting period. However, the International Accounting Standards Board (IASB) still recognizes the importance of net income and is committed to maintaining its importance (Gazzola, Amelio, 2014). The IASB considers net income and net comprehensive income as complementary performance measures and, therefore, does not intend to replace net income with net comprehensive income (Hoogervorst, 2012b). According to IFRS, net income is still the basis for computation of earnings per share, and no change is anticipated (Lurie, Shuv, 2010). Le Manh-Béna (2010) stresses that preparers and users of financial statements still prefer traditional concept of net income and do not perceive a need to redefine that concept.

Smith $(2010,99)$ argues that comprehensive income is a product of "a more comprehensive calculation of gains earned by business during a reporting period". Choi, Zang (2006) and Choi, Das, Zang (2007) point out that comprehensive income is useful in predicting changes in net income of the next period. Hoogervorst (2012a) stresses that it is important for investors to know which gains or losses, even those that are still not realised, exist in the balance sheet. However, Maines, McDaniel (2000) point out that investors may be confused because they do not always know which of the two performance measures (net income or net comprehensive income) is more appropriate in specific circumstances. Botzem (2012) argues that reporting of comprehensive income leads to a decrease in importance of operating activities for assessing a company's performance in comparison to value changes. The completeness of comprehensive income is considered its main advantage, while including unrealized gains is considered its main disadvantage. However, as stated above, net income may also include unrealized gains leading to an unreasonable increase in managers' fees and dividends. Unrealised gains should not be ignored because they can be dangerous to a company's financial health (Hoogervorst, 2014).

Reither, Smith (1996) argue that the introduction of the concept of comprehensive income did not lead to presentation of some new information, in the sense that the information that were available before is only presented in another manner thus becoming more transparent and accessible to financial statements users. Eaton, Easterday, Rhodes (2013) generally support this attitude. Starting from the objective of financial reporting, Keating (1999) firmly supports comprehensive income, arguing that the emphasis on comprehensive income is of great importance for making investment and credit decisions, because the existence of unrealized gains is an indicator of stability as a motivating factor in decision making process. The same author also highlights that comprehensive income facilitates prediction of a company's future cash flows, since unrealized components of comprehensive income could be realised in future periods.

Škarić-Jovanović (2010) argues that, if a significant portion of assets and liabilities is measured at fair value, net assets will be significantly more volatile from period to period in comparison to net assets under the concept of historical cost, because of changes in market 
prices (fair values). It implies that comprehensive income is expected to be more volatile in time than net income. Volatility resulting from changes in market prices and subjectivity in measuring fair values are the main arguments of advocates of the concept of historical cost against fair value, while supporters of fair value consider volatility as a correct reflection of economic reality (Hoogervorst, 2015). Bradbury (2016) stresses that more pronounced volatility of components of other comprehensive income than net income is one of the reasons why comprehensive income should not be presented in a single performance report, although IFRS allow such a presentation.

\section{Previous empirical research on comprehensive income}

Zülch and Pronobis (2010) note that, in most studies on comprehensive income, it is compared with net income in terms of relevance for predicting stock prices. The results of such studies are different, but more studies emphasize the superiority of net income. The research of previously mentioned authors, which observed companies included in the main index of the German stock exchange (HDAX) from 1998 to 2007, shows that comprehensive income is not superior to net income in predicting company performance. Tsuji (2013) observe financial statements of companies from the primary listing of the Tokyo Stock Exchange and finds that comprehensive income is not superior to other forms of income and cash flows for predicting future return on equity. Cheng, Cheung, Gopalakrishnan (1993) find that the informative value of operating income (as a layer of net income) and net income are significantly higher than the informative value of comprehensive income. Dhaliwal, Subramanyam, Trezevant (1999) and Mechelli, Cimini (2014) do not find that comprehensive income is more relevant than net income. On the other hand, Gazzola, Amelio (2014), on the basis of the analysis of the consolidated financial statements of companies listed on the primary market of the Czech stock exchange from 2010 to 2012, conclude that comprehensive income has the informative value and that it provides additional information for assessing financial performance. The research of Yousefi Nejad, Embong, Ahmad (2014), conducted on a sample of 764 companies listed on the primary market of the Malaysian stock exchange from 2011 to 2013, shows that components of other comprehensive income are related to share prices. Kanagaretnam, Mathieu, Shehata (2009) find that comprehensive income is more tightly related to share prices and returns than net income. However, Smith, Tse (1998) and Păşcan (2014) find that net income is more tightly related to share prices, and thus with market value of companies, than comprehensive income.

On the basis of the analysis of 90 companies in the period from 1996 to 1998, Ketz (1999) concludes that net income and comprehensive income do not differ significantly in general. The same author notes that the research neither confirms nor rejects the claims (1) that comprehensive income is relevant to users of financial statements and (2) that it is reasonable to include the statement on comprehensive income into a set of regular financial statements. Ngmenipuo (2015) and Păşcan (2014) find no statistically significant difference between net income per share and comprehensive income per share. Obradović, Karapavlović (2015) find that, in the case of companies in the 
Republic of Serbia included in the BELEXline index in 2014, generally there is no statistically significant difference between net income and net comprehensive income, i.e, that components of net other comprehensive income do not make net comprehensive income substantially different from net income. They stress that differences between net income and net comprehensive income are very significant in certain cases, but such cases are relatively rare.

Khan, Bradbury $(2014,2015)$ find that comprehensive income is significantly more volatile in time than net income in the cases of non-financial companies in the United States of America and New Zealand. Based on the research of attitudes of financial statements preparers, Smith, Tse (1998) point out that items of other comprehensive income, increase the volatility of comprehensive income, even though the company's risk remains unchanged. Henry (2011) also finds that components of comprehensive income are more volatile than net income, which is proven by comparing their standard deviations. On the other hand, a high volatility can lower share prices and increase costs of capital.

\section{Research results}

The analysis reveals that the changes in revaluation surplus and gains or losses on financial instruments available for sale are the most frequent components of other comprehensive income in the observed companies. These components can be found in the Statement of other comprehensive income of $28(21.21 \%)$ and $24(18.18 \%)$ companies, respectively. Actuarial gains or losses on defined employee benefit plans are present in 14 companies $(10.61 \%)$. Gains and losses on investments in equity instruments are present in only one company, and the same is the case with gains or losses on instruments of cash flow hedge. The rest three components provided in the official form of the Statement of other comprehensive income (share in other comprehensive income of associates, gains or losses on translation of financial statements of foreign operations, and gains or losses on hedges of net investments in foreign operations) are not present in any of the observed companies.

The observed companies have one component of other comprehensive income on average, and none of the companies has more than three components. In the case of 15 companies $(11.36 \%)$, there is the position of tax on comprehensive income, while remaining companies do not have that position, which means that their gross comprehensive income and net comprehensive income are equal. In the case of 80 observed companies (60.61\%), there are no components of other comprehensive income, which means that net comprehensive income is equal to net income.

In the case of 25 observed companies (18.94\%), net other comprehensive income is negative (loss), which means that net comprehensive income is less than net income. In the case of 27 companies (20.45\%), net other comprehensive income is positive (profit), which means that net comprehensive income is higher than net income. In four cases $(3.03 \%)$, net income and net comprehensive income have the opposite sign 
- in three cases net comprehensive income has a positive value and net income has a negative value, while in one case the situation is quite opposite. In 113 cases (85.61\%), net other comprehensive income is in the range from $-10 \%$ to $+10 \%$ of the absolute value of net income.

In order to test the first research hypothesis, we have conducted a correlation analysis. The results presented in Table 2. indicate that there is a very strong, positive and statistically significant $(p=0.000)$ correlation between net income and net comprehensive income, which means that we should reject the first hypothesis.

Table 2. Correlation matrix

\begin{tabular}{|c|c|c|c|}
\hline \multicolumn{2}{|c|}{} & net income & $\begin{array}{c}\text { net comprehensive } \\
\text { income }\end{array}$ \\
\hline \multirow{3}{*}{ net income } & Pearson Correlation & 1 & $0.980^{* *}$ \\
\cline { 2 - 4 } & Sig. (2-tailed) & & 0.000 \\
\cline { 2 - 4 } & $\mathrm{N}$ & 132 & 132 \\
\hline \multirow{3}{*}{ net comprehensive income } & Pearson Correlation & $0.980^{* *}$ & 1 \\
\cline { 2 - 4 } & Sig. (2-tailed) & 0.000 & 132 \\
\cline { 2 - 4 } & N & 132 & \\
\hline \multirow{2}{*}{$* *$ Correlation is significant at the 0.01 level (2-tailed). } & & \\
\hline
\end{tabular}

Source: Authors' calculation

A more detailed analysis based on segmenting the sample according to the company size shows that the correlation between net income and net comprehensive income is the strongest for large companies $(0.997 ; p=0.000)$ and it is also very strong for medium-sized companies $(0.956 ; p=0.000)$. In both cases, the correlation is positive. However, the correlation is medium and negative for small companies $(-0.467 ; p=$ 0.005). Because of very small number of micro companies in our sample, the results of analyses for companies of this size cannot be considered representative. The analysis based on segmenting the sample according to the company legal form shows that the correlation between net income and net comprehensive income is stronger for limited liability companies $(0.994 ; p=0.000)$ than for stock companies $(0.968 ; p=0.000)$. The results of the correlation analysis for companies of other legal forms are not sufficiently representative or such analysis cannot be performed because of small number of those companies in the sample.

In order to determine whether parametric test is applicable for examining the second research hypothesis, we perform normality tests for both net income and net comprehensive income. The results of those tests are shown in Table 3. Since the sample is higher than $50(n=132)$, we rely to the statistical significance of KolmogorovSmirnov tests, which is less than 0.05 in both cases. We conclude that both net income and net comprehensive income are not normally distributed. Therefore, we use the nonparametric Wilcoxon Signed Ranks Test, the results of which are shown in Table 4. The abovementioned test, in fact, examines whether the inclusion of components of other comprehensive income significantly change performance measure. 
Table 3. Normality tests for net income and net comprehensive income

\begin{tabular}{|c|c|c|c|c|c|c|}
\hline & \multicolumn{3}{|c|}{ Kolmogorov-Smirnov } & \multicolumn{3}{c|}{ Shapiro-Wilk } \\
\cline { 2 - 7 } & Statistic & df & Sig. & Statistic & df & Sig. \\
\hline net income & 0.227 & 132 & 0.000 & 0.703 & 132 & 0.000 \\
\hline net comprehensive income & 0.229 & 132 & 0.000 & 0.716 & 132 & 0.000 \\
\hline
\end{tabular}

Source: Authors' calculation

Table 4. Wilcoxon Signed Ranks Test for the difference between net income and net comprehensive income

\begin{tabular}{|c|c|}
\hline & net comprehensive income - net income \\
\hline$Z$ & -1.612 \\
\hline Asymp. Sig. (2-tailed) & 0.107 \\
\hline
\end{tabular}

Source: Authors' calculation

As the significance of Wilcoxon Signed Ranks is higher than 0.05, we conclude that there is no statistically significant difference between net comprehensive income and net income. It means that we should reject the second hypothesis. The measure of effect size $r$ of 0.099 denotes a small difference between net comprehensive income and net income according to Cohen's criteria (Pallant, 2011). The difference is also not statistically significant in all mentioned sample segments (small, medium-sized and large companies; limited liability and stock companies).

In order to test the third research hypothesis, two indicators of return on equity (ROE) are computed for each sample company $-\mathrm{ROE}_{\mathrm{NI}}$ and $\mathrm{ROE}_{\mathrm{NCI}} \mathrm{ROE}_{\mathrm{NI}}$ is computed by dividing net income with average owners' equity, while $\mathrm{ROE}_{\mathrm{NCI}}$ is computed by dividing net comprehensive income with average owners' equity. Normality tests (Table 5.) show that empirical distributions of both $\mathrm{ROE}_{\mathrm{NI}}$ and $\mathrm{ROE}_{\mathrm{NCI}}$ do not approximate to normal, which means that parametric test are not eligible. Therefore, we use non-parametric Wilcoxon Signed Ranks Test. The significance of this test (Table 6.) is higher than 0.05, which means that there is no statistically significant difference between $\mathrm{ROE}_{\mathrm{NCI}}$ and $\mathrm{ROE}_{\mathrm{NI}}$. Therefore, the third hypothesis should be rejected. The measure of effect size $r$ of 0.035 denotes a small difference between the indicators. The difference is not statistically significant in all the observed sample segments.

Table 5. Normality tests for $\mathrm{ROE}_{\mathrm{NI}}$ and $\mathrm{ROE}_{\mathrm{NCI}}$

\begin{tabular}{|c|c|c|c|c|c|c|}
\hline & \multicolumn{3}{|c|}{ Kolmogorov-Smirnov } & \multicolumn{3}{c|}{ Shapiro-Wilk } \\
\cline { 2 - 7 } & Statistic & Df & Sig. & Statistic & Df & Sig. \\
\hline $\mathrm{ROE}_{\mathrm{NI}}$ & 0.344 & 132 & 0.000 & 0.308 & 132 & 0.000 \\
\hline $\mathrm{ROE}_{\mathrm{NCI}}$ & 0.340 & 132 & 0.000 & 0.318 & 132 & 0.000 \\
\hline
\end{tabular}

Source: Authors' calculation 
Table 6. Wilcoxon Signed Ranks Test for difference between $\mathrm{ROE}_{\mathrm{NCI}}$ and $\mathrm{ROE}_{\mathrm{NI}}$

\begin{tabular}{|c|c|}
\hline & $\mathbf{R O E}_{\mathbf{N C I}}-\mathbf{R O E}_{\mathrm{NI}}$ \\
\hline $\mathrm{Z}$ & -0.574 \\
\hline Asymp. Sig. (2-tailed) & 0.566 \\
\hline
\end{tabular}

Source: Authors' calculation

The results of statistical tests used for examining the first three hypotheses indicate that, in general, net income as a traditional performance measure and net comprehensive income as a new performance measure do not differ significantly in the case of companies in the food and beverage sector in the Republic of Serbia. However, it does not mean that the difference is not significant in all the observed companies. In that regard, the extreme case is the company in the sample whose net loss of 5,520 RSD transforms into net comprehensive profit of 338,561 RSD after including components of other comprehensive income and deducting tax on comprehensive income.

In order to test the fourth research hypothesis, we have firstly computed changes in both net income and net comprehensive income for each sample company as differences between the amounts in 2014 and 2013. Then, we have computed standard deviations and variances of those changes. As Table 7 shows, standard deviation and variance of net comprehensive income are higher than standard deviation and variance of net income, which means that net comprehensive income is more volatile than net income. The results show that we should not reject our fourth hypothesis.

Table 7. Standard deviations and variances of changes in net income and net comprehensive income

\begin{tabular}{|c|c|c|c|}
\hline & n & Std. deviation & Variance \\
\hline change in net income & 132 & $702,819.89$ & $493,955,778,427.66$ \\
\hline change in net comprehensive income & 132 & $790,548.09$ & $624,966,289,221.51$ \\
\hline
\end{tabular}

Source: Authors' calculation

\section{Conclusion}

The research in this paper reveals that, in the case of companies in the food and beverage sector in the Republic of Serbia, there is a high positive correlation between net income and net comprehensive income, and that the difference between net income and net comprehensive income is not considerably significant. It can be concluded that components of net other comprehensive income do not make net comprehensive income substantially different from net income. About $60 \%$ of companies in the sample do not have any component of net other comprehensive income, which means that net income and net comprehensive income of those companies are equal. This suggests that companies in the food and beverage sector in the Republic of Serbia mainly do not revaluate their items of intangible assets, property, plant and equipment, i.e., that they usually measure the aforementioned items of assets by using historical cost model. The observed companies, on average, have one component of other comprehensive income, and none of them has more than three components. Changes in 
revaluation surplus and gains/losses on financial instruments available for sale are the most frequent components of other comprehensive income. In addition, there is no statistically significant difference between the return on equity calculated by using net income as numerator and the return on equity calculated by using net comprehensive income as numerator. The foregoing indicates that, in general, there have been no significant changes in performance measurement in the food and beverage sector in the Republic of Serbia, because net comprehensive income as a new performance measure is not significantly different from net income as the traditional, but still available, performance measure. However, in individual cases, net comprehensive income may be very different from net income. The research results also show that net comprehensive income is more volatile in time than net income, which is in line with the expectations in the theory and the results of previous empirical studies. Since net comprehensive income is more volatile than net income and since the two performance measures can differ significantly in some cases, users of financial statements of companies in the food and beverage sector in the Republic of Serbia should take into account both performance measures when assessing past performance and predicting future performance.

\section{References}

1. Baker, C.R., Wallage, P. (2000): The Future of Financial Reporting in Europe: Its Role in Corporate Governance, The International Journal of Accounting, Vol. 35, No. 2, pp. 173-187, Elsevier.

2. Botzem, S. (2012): The Politics of Accounting Regulation: Organizing Transnational Standard Setting in Financial Reporting, Edward Elgar Publishing Limited, Chelenham, England.

3. Brauchle, G.J., Reither, C.L. (1997): SFAS No. 130: Reporting Comprehensive Income, The CPA Journal, Vol. 67, No. 10, The New York State Society of Certified Public Accountants, New York, USA, Available at: http://www.cpajournal. com/1997/1097/features/F421097.htm (date of access 8/09/2015)

4. Bradbury, M.E. (2016): Discussion of 'Other comprehensive income: a review and directions for future research', Accounting and Finance, Vol. 56, Issue 1, pp. 47-58, Wiley, Carlton, Australia.

5. Cheng, C.S.A., Cheung, J.L., Gopalakrishnan, V. (1993): On the Usefulness of Operating Income, Net Income and Comprehensive Income in Explaining Security Returns, Accounting and Business Research, Vol. 23, No. 91, pp. 195-203, Institute of Chartered Accountants in England and Wales, London, United Kingdom.

6. Choi, J.H, Zang, Y. (2006): Implications of Comprehensive Income Disclosure For Future Earning and Analysts' Forecasts, Seoul Journal of Business, Vol. 12, No. 2, Singapore Management University, Singapore, pp. 77-109. Available at: http:// ink.library.smu.edu.sg/cgi/viewcontent.cgi?article=1162\&context=soa_research (date of access 14/06/2016)

7. Choi, J.H., Das, S., Zang, Y. (2007): Comprehensive Income, Future Earning, and Market Mispricing, Working Paper: Researh Collection School of Accountancy, 
Singapore Management University, Singapore, Available at: http://ink.library.smu.edu. sg/cgi/viewcontent.cgi?article=1161\&context=soa_research (date of access 11/09/2015)

8. Delloitte Touche Tohmatsu (2007): Revised Standard on presentation of financial statements, London, England, Available at: http:/www.casplus.com/pubs/ files/0709ias1revised.pdf (date of access 02/07/2015)

9. Dhaliwal, D., Subramanyam, K.R., Trezevant, R. (1999): Is comprehensive income superior to net income as a measure of firm performance?, Journal of Accounting and Economics, Vol. 26, Issues 1-3, pp. 43-67, Elsevier BV, Amsterdam, Netherlands.

10. Eaton, T.V., Easterday, K.E., Rhodes, M.R. (2013): The Presentation of Other Comprehensive Income: FASB's Recent and Proposed Changes, The CPA Journal, Vol. 83, No. 3, pp. 32-35, The New York State Society of Certified Public Accountants, New York, USA.

11. Foster, N., Hall, N. (1996): Reporting Comprehensive Income, The CPA Journal, Vol. 66, No. 10, The New York State Society of Certified Public Accountants, New York, USA, Available at: http://www.cpajournal.com/1996/1096/features/Reportin.htm (date of access 08/09/2015)

12. Gazzola, P. \& Amelio, S. (2014): Is total comprehensive income or net income better for the evaluation of companies'financial performance?, Ekonomická revue, Vol. 17, No. 1, pp. 39-51, Faculty of Economics, Ostrava, Czech.

13. Henry, E. (2011): Presentation of Comprehensive Income: Another (Small) Step Toward Convergence, The Journal of Corporate Accounting \& Finance, Vol. 23, Issue 1, pp. 85-90. John Wiley \& Sons, Inc., Hoboken NJ, USA.

14. Hoogervorst, H. (2012a): The Imprecise Nature of Accounting: Questions on Measurement, Standard Setting and the IASB's Course for the Future, The CPA Journal, Vol. 82, No. 8, pp. 11-13, The New York State Society of Certified Public Accountants, New York, USA.

15. Hoogervorst, H. (2012b): Dispelling myths about IFRS: Introductory remarks by Hans Hoogervorst, Chairman of the International Accounting Standards Board, Available at: http:/www.ifrs.org/Alerts/PressRelease/Documents/2012/Dispelling-mythsabout-IFRS-Hans-Hoogervorst-2012.pdf (date of access 10/09/2015)

16. Hoogervorst, H. (2014): The dangers of ignoring unrealised income, Speech by Hans Hoogervorst, International Accounting Standards Board Chairman, IFRS Conference Tokyo, Available at: http:/www.ifrs.org/Alerts/Conference/Documents/2014/ Speech-Hans-Hoogervorst-Dangers-of-ignoring-unrealised-income-September-2014.pdf (date of access 15/06/2016)

17. Hoogervorst, H. (2015): Historical cost versus fair value measurement: les extrémes se rejoignent, International Accounting Standards Board Speech: IFRS Conference, Paris, Available at: http://www.ifrs.org/alerts/conference/documents/2015/ hans-hoogervorst-speech-paris-june-2015.pdf (date of access 22/03/2016)

18. Kanagaretnam, K., Mathieu, R., Shehata, M. (2009): Usefulness of comprehensive 
income reporting in Canada, Journal of Accounting and Public Policy, Vol. 28, Issue 4, pp. 349-365, Elsevier Inc., New York, USA.

19. Ketz, E. (1999): Comprehensive Income: What Do the Numbers Disclose?, The Journal of Corporate Accounting \& Finance, Vol. 10, Issue 4, pp. 79-96, John Wiley \& Sons, Inc., Hoboken NJ, USA.

20. Khan, S., Bradbury. M.E. (2014): Volatility and risk relevance of comprehensive income, Journal of Contemporary Accounting \& Economics, Vol. 10, Issue 1, pp. 76-85, Elsevier Ltd.

21. Khan, S., Bradbury, M.E. (2015): The volatility of comprehensive income and its association with market risk, Accounting \& Finance, Early View (Online Version of Record published before inclusion in an issue), Wiley, Carlton, Australia.

22. Le Manh-Béna, A. (2010): Is comprehensive income required by IAS 1 relevant for users? A review of the literature, Available at: https://halshs.archives-ouvertes.fr/ halshs-00494511/document (date of access 02/07/2015)

23. Lurie, E., Shuv, S. (2010): Returning the Relevancy of the P\&L: A Proposed Model, The CPA Journal, Vol. 80, No. 12, pp. 22-27, The New York State Society of Certified Public Accountants, New York, USA.

24. Maines, L.A., McDaniel, L. (2000): Effects of Comprehensive-Income Characteristics on Nonprofessional Investors' Judgments: The Role of FinancialStatement Presentation Format, The Accounting Review, Vol. 75, No. 2, pp. 179207, American Accounting Association, Sarasota FL, USA.

25. Mechelli, A., Cimini, R. (2014): Is Comprehensive Income Value Relevant and Does Location Matter? European Study, Accounting in Europe, Vol. 11, Issue 1, pp. 5987, Routledge, Abingdon, United Kingdom.

26. Melville, A. (2011): International Financial Reporting Standards: A Practical Guide ( $3^{\text {rd }}$ ed.), Pearson Education Limited, Harlow, England.

27. Munter, P. (1997): New Standards on Segment Reporting and Comprehensive Income, The Journal of Corporate Accounting and Finance, Vol. 9, No. 1, pp. 117 125, John Wiley \& Sons, Inc., Hoboken NJ, USA.

28. Needles, B.E., Powers, M. (2013): International Financial Reporting Standards: An Introduction, South-Western, Cengage Learning, Mason, USA.

29. Ngmenipuo, I.M. (2015): The Impact of Comprehensive Income Reporting on Financial Performance of Ghanian Firms with Public Accountability, International Journal of Economics, Commerce and Management, Vol. 3, Issue 3, United Kingdom, Available at: http://ijecm.co.uk/wp-content/uploads/2015/03/3330.pdf (date of access 11/09/2015)

30. Obradović, V., Karapavlović, N. (2015): Finansijsko izveštavanje o ukupnom dobitku ili gubitku - slučaj nefinansijskih kompanija iz indeksne korpe BELEXline, Računovodstvo, 59(4), str. 49-64, Savez računovođa i revizora Srbije, Beograd, Srbija. 
31. Pallant, J. (2011): SPSS - Priručnik za preživljavanje (Prevod 4. izdanja), Mikro knjiga, Beograd, Srbija.

32. Păşcan, I. (2014): Does comprehensive income tell us more about an entity's performance compared to net income? Study on Romanian listed entities, Procedia Economics and Finance, Vol. 15, pp. 1077-1082, Elsevier.

33. Rees, L.L., Shane, P. B. (2012): Academic Research and Standard-Setting: The Case of Other Comprehensive Income, Accounting Horizons, Vol. 26, No. 4, pp. 789-815, American Accounting Association, Sarasota FL, USA.

34. Reither, C.L., Smith, P.A. (1996): Comprehensive Income: How To Apply the Rules of FASB's Recent Exposure Draft, The Journal of Corporate Accounting \& Finance, Vol. 7, Issue 4, pp. 29-38, John Wiley \& Sons, Inc., Hoboken NJ, USA.

35. Reither, C.L., Brauchle, G.J. (1997): FASB Issues New Standard On Reporting Comprehensive Income, The Journal of Corporate Accounting \& Finance, Vol. 9, Issue 1, pp. 1-8, John Wiley \& Sons, Inc., Hoboken NJ, USA.

36. Smith, P.A., Tse, S. (1998): Reporting Comprehensive Income: Does It Really Affect Stock Prices?, The Journal of Corporate Accounting \& Finance, Vol. 9, Issue 4, pp. 75-86, John Wiley \& Sons, Inc., Hoboken NJ, USA.

37. Smith, B.P. (2010): Introductory Financial Accounting and Reporting, McGrawHill Education, Maidenhead, England.

38. Statement of Financial Accounting Concepts No. 3: Elements of Financial Statements of Business Enterprises, Financial Accounting Standards Board, 1980, USA.

39. Stefanović, R. (1993): Finansijsko izveštavanje kao osnova za donošenje odluka kvalitativni aspekt, Knjigovodstvo, 38(12), str. 9-15, Savez računovođa i revizora Srbije, Beograd, Srbija.

40. Škarić-Jovanović, K. (2010): Normativna osnova finansijskog izveštavanja i finansijska kriza, Acta Economica, 8(12), str. 103-124, Ekonomski fakultet Univerziteta u Banjoj Luci, Banja Luka, Republika Srpska.

41. Škarić-Jovanović, K. (2016): Uticaj promjena u poslovnom okruženju i normativnoj osnovi finansijskog izvještavanja na iskaznu moć mjerila finansijskih performansi kompanija, Acta Economica, 14(24), str. 31-51, Ekonomski fakultet Univerziteta u Banjoj Luci, Banja Luka, Republika Srpska.

42. Tsuji, C. (2013): Comprehensive Income and Stock Return: Evidence from the Tokyo Stock Exchange, Journal of Management and Sustainbility, Vol. 3, No. 3, pp. 142147, The Canadian Center of Science and Education, Toronto, Canada.

43. Walton, P. (2011): An Executive Guide to IFRS: Content, Costs and Benefits to Business, John Wiley \& Sons, Ltd., Chichester, United Kingdom.

44. Wilson, A. (2007): The relevance and reliability of fair value measurement, in: Walton, P. (Ed.). The Routhledge Companion to Fair Value and Financial Reporting, pp. 196-209, Routledge, Abingdon and Oxon, USA and Canada.

45. Yen, A.C., Hirst, E., Hopkins, P.E. (2007): A Content Analysis of the Comprehensive 
Income Exposure Draft Comment Letters, Research in Accounting Regulation, Vol. 19, pp. 53-79, J A I Press Inc., New York, USA.

46. Yousefi Nejad, M., Embong, Z., Ahmad, A. (2014): Value Relevance of Other Comprehensive Income, International Management Accounting Conference 7: 2-3 December 2014, University Kebangsaan Malaysia, Malaysia, Available at: http:// conference.ukm.my/IMAC7/IMAC7/paper/viewFile/2285/10 (date of access 11/09/2015)

47. Zülch, H., Pronobis, P. (2010): Comprehensive Income and Its Individual Components under IFRS, HHL Working Paper No. 95, Leipzig, Germany, Available at: http://www.hhl.de/fileadmin/texte/publikationen/arbeitspapiere/hhlap0095.pdf (date of access 11/07/2015)

\title{
FINANSIJSKO IZVEŠTAVANJE O UKUPNOM REZULTATU U SEKTORU HRANE I PIĆA U REPUBLICI SRBIJI
}

\author{
Vladimir Obradovic ${ }^{3}$, Nemanja Karapavlovic ${ }^{4}$
}

\begin{abstract}
Apstrakt
U radu se razmatra finansijsko izveštavanje o neto ukupnom rezultatu preduzeća u sektoru hrane i pića u Republici Srbiji. Cilj istraživanja je da se ispita da li je uvođenje koncepta neto ukupnog rezultata donelo značajne informacije za korisnike finansijskih izveštaja. Analiza je sprovedena na uzorku od 132 preduzeća iz pomenutog sektora, na bazi finansijskih izveštaja za 2014. godinu. Utvrđeno je da između neto rezultata i neto ukupnog rezultata postoji veoma visoka pozitivna korelacija; da se neto rezultat i neto ukupan rezultat statistički ne razlikuju značajno; da ne postoji statistički značajna razlika između stope prinosa na sopstvena sredstva izračunate na osnovu neto rezultata i stope prinosa na sopstvena sredstva izračunate na osnovu neto ukupnog rezultata; i da je neto ukupan rezultat promenljiviji u vremenu nego neto rezultat.
\end{abstract}

Ključne reči: neto ukupan rezultat, neto rezultat, neto ostali rezultat, sektor hrane i pića

3 Docent, dr Vladimir Obradović, Univerzitet u Kragujevcu - Ekonomski fakultet, Đure Pucara Starog 3, Kragujevac, Srbija, Telefon: +381 34303 590, E-mail: vobradovic@kg.ac.rs

4 Master ekonomista, Nemanja Karapavlović, Asistent, Univerzitet u Kragujevcu - Ekonomski fakultet, Đure Pucara Starog 3, Kragujevac, Srbija, Telefon: +381 34303 528, E-mail: nkarapavlovic@kg.ac.rs 
ECONOMICS OF

AGRICULTURE

\section{CONTENT}

1. Željko Anđelković, Aleksandra Dragin, Sanja Božić, Kristina Košić

EMOTIONAL EXHAUSTION AND JOB SATISFACTION OF TOUR GUIDES IN RURAL AREAS . . . . . . . . . . . . . . 11

2. Sanja Đukić, Danica Glavaš-Trbić, Nikola Banjac

MANAGEMENT PROBLEMS OF RURAL DEVELOPMENT IN FRUŠKA GORA . . . . . . . . . . . . . . . . . . . . 27

3. Ivana Ilić, Bojan Krstić, Sonja Jovanović

ENVIRONMENTAL PERFORMANCES OF AGRICULTURE IN THE EUROPEAN UNION COUNTRIES . . . . . . . . . . . . . 41

4. Nataša Kljajić, Jonel Subić, Zorica Sredojević

PROFITABILITY OF RASPBERRY PRODUCTION

ON HOLDINGS IN THE TERRITORY OF ARILJE. . . . . . . . . . . 57

5. Aleksandar Maksimović, Zoran Grgić, Ferhat Ćejvanović

MULTI-ATTRIBUTE ANALYSIS OF ORCHARD ACCORDING

TO THE INTEGRATED PRODUCTION CONCEPT . . . . . . . . . . 69

6. Ozrislava Milinković, Branislav Jakić, Slobodan Vuksanović,

Dragana Macura, Milica Šelmić

MULTI- CRITERIA DECISION BASED APPROACH

TO SELECTING THE TYPE OF INDUSTRIAL HALLS

USED IN FOOD INDUSTRY $\ldots \ldots \ldots \ldots$. . . . . . . . . . 81

7. Gordana Nikić, Ljubiša Stamatović, Azra Sućeska

EMOTIONAL COMPETENCIES AND PERSONALITY

TRAITS OF MANAGERS IN MODERN AGROBUSINESS. . . . . . . .97

8. Vladimir Obradović, Nemanja Karapavlović

FINANCIAL REPORTING OF COMPREHENSIVE INCOME

IN THE FOOD AND BEVERAGE SECTOR

IN THE REPUBLIC OF SERBIA . . . . . . . . . . . . . . 113 
9. Aleksandar Ostojić, Nebojša Savić, Željko Vaško

CONSUMER ATTITUDES

ON BUYING FISH IN BANJA LUKA . . . . . . . . . . . . . . . 129

10. Radivoj Prodanović, Boris Kuzman, David Jovović, Lazar Ozegović

MARKET AND TRADE OF ORGANIC FRUITS IN SERBIA $\ldots . . .141$

11. Predrag Vukadinović, Aleksandar Damnjanović, Ljiljana Dimitrijević

ANALYSIS OF THE SALES AND INCOMES BETWEEN

DIFFERENT CATEGORIES OF AGRICULTURAL PRODUCTS . . . 157

12. Jugoslav Aničić, Svetlana Vukotić, Goran Maksimović

THE POSSIBILITIES AND LIMITATIONS

OF ENTREPRENEURSHIP DEVELOPMENT

IN AGRICULTURE IN SERBIA . . . . . . . . . . . . . . 171

13. Željko Bjelajac, Marijana Dukić - Mijatović, Joko Dragojlović

FOOD SAFETY AS ONE OF THE MAIN SAFETY $P$

REOCCUPATIONS OF A MODERN MAN . . . . . . . . . . . . . 191

14. Milan Bradić, Ljiljana Kosar, Lukrecija Djeri, Svetlana Vukosav, Vuk Garača

ECO-LABELLING OF ACCOMMODATION FACILITIES

AND ITS PERCEPTION BY RURAL TOURISTS:

CASE STUDY OF VOJVODINA . . . . . . . . . . . . . . 205

15. Vaso Jegdić, Iva Škrbić, Srđan Milošević

MODELS OF ENTREPRENURSHIP DEVELOPMENT

IN RURAL TOURISM DESTINATIONS IN VOJVODINA . . . . . . . 221

16. Duško Kuzović

MUSEUM OF VERNACULAR ARCHITECTURE OF WESTERN SERBIA

- Representative curtilages of the area surrounding middle

course of the river Drina and Podgorina . . . . . . . . . . . 239

17. Branko Mihailović, Zoran Simonović, Nikola Ćurčić

AGRICULTURAL RESOURCES AND DEVELOPMENT

PRIORITIES OF THE MUNICIPALITY OF STARA PAZOVA. . . . . 259

18. Radmilo Nikolić, Aleksandra Fedajev, Vidoje Stefanović, Silvana Ilić

THE AGRICULTURE SECTOR IN WESTERN BALKANS

- SOME CHARACTERISTICS OF DEVELOPMENT. . . . . . . . . . 275

19. Vladimir Njegomir, Rajko Tepavac, Nenad Ivanišević

ALTERNATIVE SOURCES OF FINANCING

ENTREPRENEURIAL UNDERTAKINGS IN AGRICULTURE . . . 295

Economics of Agriculture, Year 64, No. 1 (1-404) 2017, Belgrade 
20. Daniela Nuševa, Kristina Mijić, Dejan Jakšić

THE PERFORMANCES OF COFFEE PROCESSORS

AND COFFEE MARKET IN THE REPUBLIC OF SERBIA . . . . . . 307

21. Svetlana Roljević Nikolić, Predrag Vuković, Biljana Grujić

MEASURES TO SUPPORT THE DEVELOPMENT OF ORGANIC

FARMING IN THE EU AND SERBIA . . . . . . . . . . . . 323

22. ŽeljkoVojinović, Vera Zelenović, DragoCvijanović

PROGRAM OF STATE SUPPORT

TO AGRICULTURAL CREDITING. . . . . . . . . . . . . . . . 339

23. Nikola Vuksanović, Dragan Tešanović, Bojana Kalenjuk,

Milijanko Portić, Marija Knežević

SOCIO-DEMOGRAPHIC CHARACTERISTICS

AS DETERMINANTS OF DIFFERENCES

IN PERCEPTION OF LOCAL GASTRONOMY . . . . . . . . . . . . 359 